\title{
Avaliação de transferência de imunidade passiva em potros Quarto de Milha e Paint Horse
}

Fernanda Tamara Neme Mobaid Agudo Romão ${ }^{[a]}$, Cassiano de Carvalho Lopes ${ }^{[b]}$

${ }^{[a]}$ Faculdade de Ensino Superior e Formação Integral (FAEF), Garça, SP, Brasil

${ }^{[b]}$ Médico veterinário, Bauru, SP, Brasil

*Autor correspondente

e-mail: ftnmaromao@gmail.com

\section{Resumo}

A égua apresenta placenta do tipo epiteliocorial difusa, que apresenta seis camadas teciduais entre a circulação sangüínea materna e a fetal, compreendendo o endotélio capilar materno, tecido conjuntivo uterino, epitélio uterino, epitélio coriônico, tecido conjuntivo fetal e endotélio capilar fetal, que promovem uma barreira na transferência transplacentária de anticorpos. Portanto, os equinos neonatos nascem hipo ou agamaglobulinêmicos e a transferência de imunidade passiva está diretamente associada à ingestão e absorção de colostro. Este estudo objetivou analisar a transferência de imunidade passiva em 15 potros da raça Quarto de Milha e 15 potros da raça Paint Horse, todos puros de origem, nascidos de éguas multíparas ou não. As éguas foram cobertas ou inseminadas artificialmente, sendo que destas cinco eram receptoras. Todas as éguas foram assistidas durante gestação, onde permaneceram a pasto e se alimentavam de capim Tifton, com sal e água à vontade. Todas as éguas foram vacinadas em duas doses, com intervalo de 30 dias, contra tétano, encefalomielite, rinopneumonite, influenza e leptospirose. Receberam aplicações de estreptomicina no $3^{\circ}, 6^{\circ}$ e $9^{\circ}$ mês gestacional. Foram utilizados todos os potros oriundos dessas éguas $(n=30)$, puros de origem, neonatos, sem distinção de sexo, que permaneceram com as mães em piquetes maternidade onde mamaram colostro ad libidum. Todos os partos foram assistidos e em nenhum houve necessidade de intervenção. Amostras de sangue venoso foram colhidas dos potros 24 horas após o nascimento, através de venopunção da jugular. O sangue foi colhido e acondicionado em tubos com anticoagulante e, posteriormente, foi analisado através de teste comercial (IgG Test ${ }^{\circledR}$ ) para determinação dos níveis de imunoglobulinas, conforme instruído pelo fabricante. Os resultados encontrados foram: 90\% (27/30) apresentaram níveis de IgG acima de $800 \mathrm{mg} / \mathrm{dL}$, demonstrando que houve excelente transferência de imunidade passiva. Apenas 10\% (3/30) apresentaram níveis de IgG entre 400 a $800 \mathrm{mg} / \mathrm{dL}$, demonstrando que houve falha 
parcial de transferência de imunidade passiva. Com base nos resultados dos testes, a terapia com 1 litro plasma hiperimune foi estabelecida nos três potros que apresentavam falha parcial de transferência de imunidade paasiva. Conclui-se, no presente estudo, que um bom manejo sanitário com imunização das éguas e reforço vacinal durante o período gestacional aumentam a produção de colostro de boa qualidade e, consequentemente, possibilitam a transferência de imunidade passiva de maneira adequada. Testes rápidos de detecção de níveis de IgG são essenciais para identificar potros que apresentam principalmente falha parcial de transferência de imunidade passiva e para estabelecer a terapia com plasma hiperimune de maneira rápida e adequada. 0 colostro de boa qualidade fornece níveis de imunoglobulinas adequados a maioria dos neonatos equinos.

Palavras-chave: Imunoglobulinas. Colostro. Neonatos. 